\title{
APLIKASI PEMASARAN ETALASE UD. KEDUNG ALUMINIUM BERBASIS WEB
}

\author{
Chayadi $^{1)}$, Siti Mujilahwati ${ }^{2)}$, Nur Qomariyah Nawafilah ${ }^{2)}$, \\ ${ }^{1)}$ Program Studi Teknik Informatika Universitas Islam Lamongan \\ ${ }^{2)}$ Dosen Fakultas Teknik Prodi Teknik Informatika Universitas Islam Lamongan \\ E-mail :abadicahaya147@gmail.com ${ }^{1}$, Moedjee@gmail.com ${ }^{2}$, nq.nawafil@yahoo.com ${ }^{3}$
}

\begin{abstract}
Abstrak
Penggunaan teknologi informasi khususnya internet dalam berbagai kegiatan dan perkantoran terkait dengan aspek kebutuhan yang secara tidak langsung merupakan tantangan bagi pihak terkait untuk mengharuskan penggunaan komputer secara maksimal. Serta Merancang sebuah sistem untuk membantu dan mempermudah perusahaan dalam menampilkan informasi serta mengembangkan binisnya agar lebih dikenal banyak masyarakat. UD. Kedung Aluminium bergerak dalam bidang jasa pembuatan etalase. Serta melayani kebutuhan masyarakat mengenai jenis produk, pemesanan, pengiriman maupun pembelian etalase. Metode yang digunakan adalah E-Commerce yang cara pembayaran dilakukan dengan transaksi ke bank dan Cod. Alat bantu yang digunakan untuk merancang sistem yaitu, FOD (Flow of Document), Context Diagram, DFD (Data Flow Diagram), ERD (Entity Relationship Diagram) dan kamus data. Teknik Pengumpulan data menggunakan wawancara dan observasi. Dan aplikasi yang digunakan dalam pemuatan sistem yaitu PHP dan MySQL. Sistem ini dibuat agar dapat membantu mempercepat proses penyelesaian penjualan seperti pada proses pemasaran produk etalase.
\end{abstract}

Kata kunci : Sistem informasi, PHP, pemasaran Etalase, Berbasis Web.

\begin{abstract}
The use of information technology, especially the Internet in a variety of activities and offices related to aspects of the requirement that indirectly is a challenge for the parties concerned to require that computers use as a maximum. Also Designing a system to assist and easier the company in the information display and develop businessto be more familiar to many people. UD. Kedung Aluminum is engaged in the manufacture of etalase . As well as serving the needs of the community regarding the type of products, ordering , delivery and purchase of etalase. The method used is the E - Commerce that the way of payments are made by the transaction to the bank and Cod.The tools used to design a system that are, FOD (Flow of Document), Context Diagram, DFD (Data Flow Diagram), ERD (Entity Relationship Diagram) and datadictionary. Data collection techniques using interviews and observation. And applicationsused in the loading system is PHP and MySQL. This system was designed to help speed up the process of completion of work as in the process of etalase product marketing.
\end{abstract}

Keywords : Information Systems, PHP, Etalase Marketing, Web-Based 


\section{PENDAHULUAN}

Penggunaan teknologi informasi khususnya internet dalam berbagai kegiatan dan perkantoran terkait dengan aspek kebutuhan yang secara tidak langsung merupakan tantangan bagi pihak terkait untuk mengharuskan penggunaan komputer secara maksimal. Dengan hal tersebut, maka beberapa pekerjaan yang seharusnya dilakukan secara manual, dengan bantuan komputerisasi, maka pengolahan yang manual tersebut digital khususnya pada penggunaan internet. Kehadiran internet ini memunculkan media baru yang dapat menjangkau semua kalangan secara cepat, tepat, dan bersamaan dengan biaya yang murah. Internet adalah media yang mempunyai manfaat besar bagi manusia, halhal tersebut tidak lepas dari berbagai karakteristik dari internet sendiri, internet memberikan berbagai fasilitas yang dapat dirasakan pengguna karena internet dapat menjadi media penyampaian informasi. Salah satu fasilitas yang digunakan sebagai media penyampaian informasia dalah HTTP.

Sebagai studi kasus misalnya pada perusahaan UD. Kedung Aluminium sistem pemesanannya masih dilakukan secara langsung atau pesan di tempat. Selain itu semua transaksi masih menggunakan bon, kwitansi, faktur yang secara keseluruhan menggunakan kertas. Perhitungan nilai jual yang dihitung berdasarkan harga modal juga dihitung menggunakan media yang sangat sederhana. Terkadang antara satu barang dengan yang lainnya tidak konsisten perhitungan nilai jualnya. Kondisi ini semakin lama membuat pemilik usaha ini mulai berfikir untuk mempermudah proses transaksi mulai dari perhitungan modal, keuntungan, diskon dan lain sebagainya termasuk menambah distribusi area jual ke media yang lebih popular saat ini yaitu internet agar dapat bersaing dengan usaha dagang lainnya. Maka dari itu dalam laporan ini, penulisakan membuat suatu sistem Aplikasi Pemasaran Etalase UD. Kedung Aluminium Berbasis Website yang mana cara pemesanannya bisa langsung melalui web tersebut dan bisa memilih dan menentukan model yang ingin di pesannya sendiri agar lebih mudah untuk pemesanannya.

\section{PEMBAHASAN \\ Perancangan Sistem}

Perancangan system adalah upaya perusahaan untuk memulai memiliki sistem baik yang lama maupun untuk memulai memiliki system baru. Perancangan system dilakukan setelah mendapat gambaran dengan jelas mengenai apa yang harus dikerjakan. Rancangan ini mengidentifikasikan komponenkomponen sistem yang dirancang secara rinci. Rancangan situs yang diusulkan terdiridari 2 bagian utama, yaitu bagian administrator untuk merawat dan mengupdate isi situs, danbagian yang kedua adalah bagian untuk user. Untuk halaman administrator sebelum masuk harus melalui proses login dulu. User tidak bias melakukan transaksi sebelum melakukan login terlebih dahulu, bias disebut sebagai member, dan hanya bias melihat-lihat produk saja.

\section{Diagram level konteks}

Diagram konteks adalah diagram yang terdiri dari suatu proses dan menggambarkan ruang lingkup suatu sistem. Diagram konteks merupakan level tertinggi dari DFD yang menggambarkan seluruh input ke sistem atau output dari sistem. Ia akan memberi gambaran tentang keseluruhan sistem. Sistem dibatasi oleh boundary (dapat digambarkan dengan garis putus). Dalam diagram konteks hanya ada satu proses. 


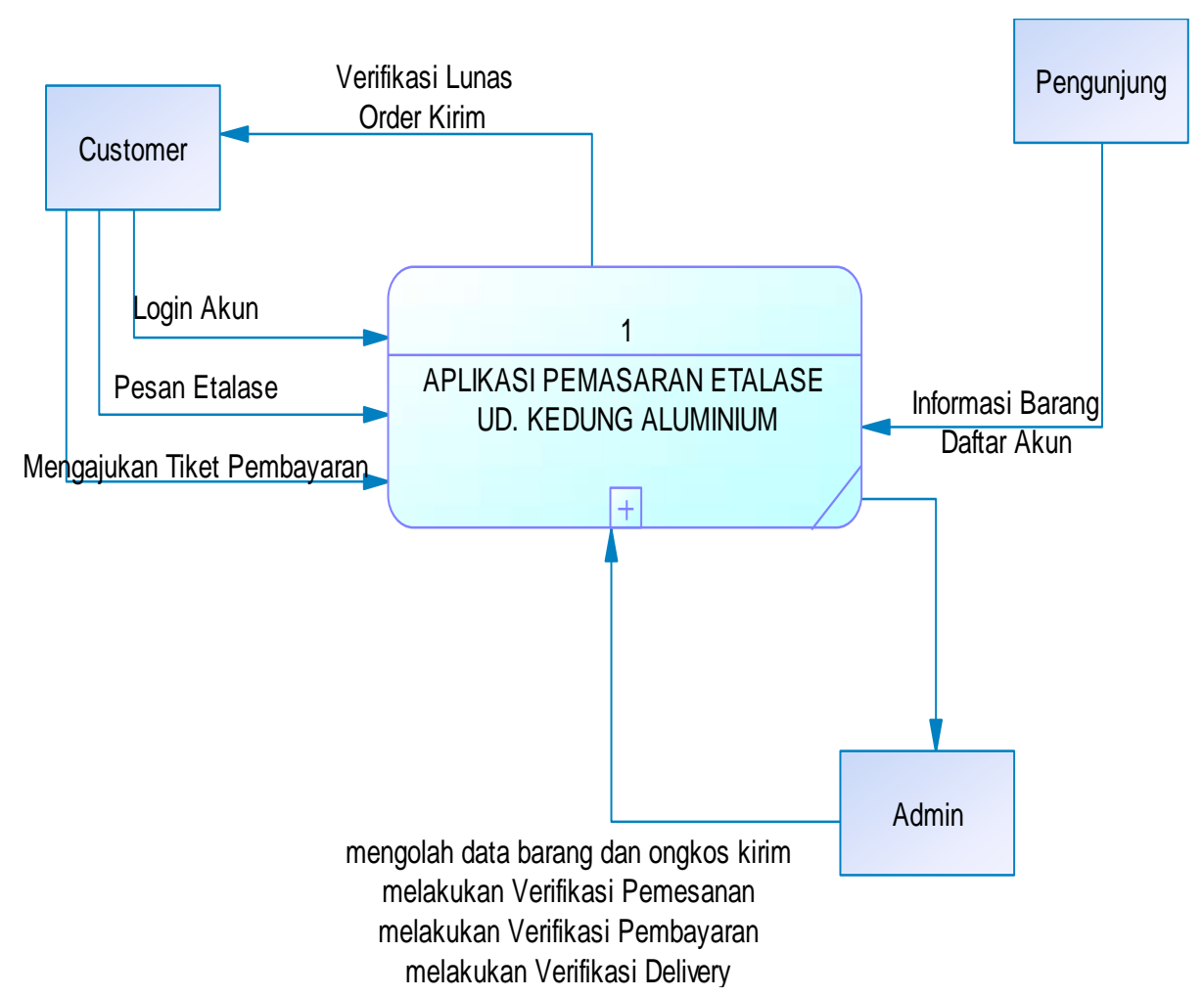

Gambar 1. Context diagram

a) Tugas dari admin adalah mengelola seluruh data-data seperti transaksi barang dll sehingga akan menjadi sebuah informasi yang dapat dilihat oleh pengunjung website tersebut.

b) Admin juga bertugas untuk melayani pembelian barang dan bertugas membuatkan bukti apa bila ada yang melakukan transaksi.

c) Pembeli hanya dapat melihat informasi saja kalau belum melakukan login sehingga apabila pelanggan ingin melakukan pembelian atau transaksi pembelih arus melakukan login dulu sebagai sarat pembelian.

d) Setiap bulan admin akan membuatkan laporan transaksi untuk diserahkan kepada pemilik usaha

\section{Data Flow Diagram Level 0}

DFD level 0 merupakan penjabaran dari diagram konteks, yang pada level ini sudah menjurus kepada suatu proses dan merupakan gabungan secara keseluruhan yang melibatkan semua kesatuan secara lengkap. 


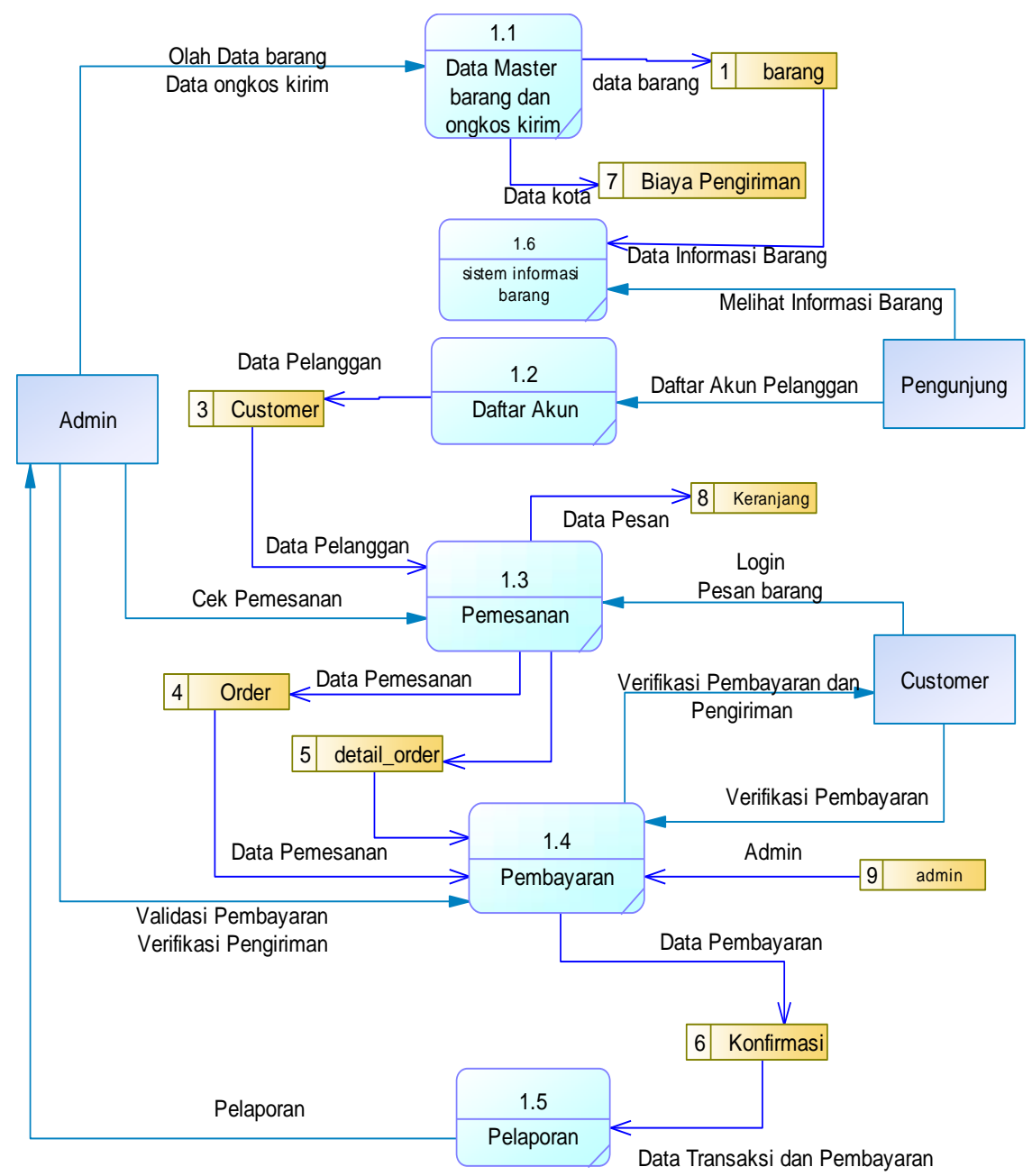

Gambar 2. DFD level 0

1) Admin melakukan login untuk mengolah data.

2) Admin akan menginputkan atau pun update data produk sehingga akan keluar informasi tentang produk yang di jual sehingga pembeli dapat melihat berbagai info di website.

3) Admin juga akan mengolah seluruh data transaksi sehingga admin mengetahui datadata transaksi yang nantinya akan di jadikan laporan kepada pemilik usaha.

4) Customer akan login/ sign up dulu sebelum melakukan transaksi. Setiap bulan admin/ pegawai akan menyetorkan hasil penjualan berupa laporan kepada pemilik usaha.

\section{Uji Coba Sistem dan Program}

Implementasi sistem dimulai dari tahap uji coba. Hal ini dilakukan agar sistem yang dijalankan dapat memberi kenyamanan bagi pengguna dan menghindari kesalahan dalam sistem yang dibuat. Pada tahap ini, dilakukan uji coba pada sistem dan program tujuannya untuk memastikan semua komponenkomponen dari sistem telah berfungsi sesuai dengan yang diinginkan.

Pengujian ini terfokus pada kebutuhan dari penggunaan sistem yang telah disebutkan pada tahap analisis, cara pengujiannya dengan menjalankan program satu persatu dari kebutuhan yang telah disusun. Semua kelengkapan dari user dan administrator telah dijabarkan dan dari uji coba yang di lakukan, di temukan beberapa kelemahan dan kesalahan pada beberapa fungsi dalam pengubahan data 
oleh administrator, setelah mengetahui kesalahan yang terjadi dan untuk menyelesaikan kesalahan tersebut dilakukan pada tahap selanjutnya White-Box testing.

Chayadi/ Aplikasi Pemasaran Etalase Ud. Kedung Aluminium Berbasis Web/JT,Vol 9 No.1, Maret 2017, pp 41 - 48

Pengujian perlu dilakukan untuk mencari kesalahan atau kelemahan yang mungkin terjadi. Pengujian sistem ini termasuk juga pengujian program secara menyeluruh mulai dari halaman login, halaman admin, dan halaman member.

\section{a. Halaman Login}

Pengujian pada halaman login untuk memastikan bahwa sistem telah berjalan sesuai dengan yang diinginkan. Pada gambar 3 . berikut halaman login akan diuji dengan memasukkan nama pengguna dan kata sandi tertentu yang sengaja tidak disesuaikan dengan data yang sudah ada pada basis data.

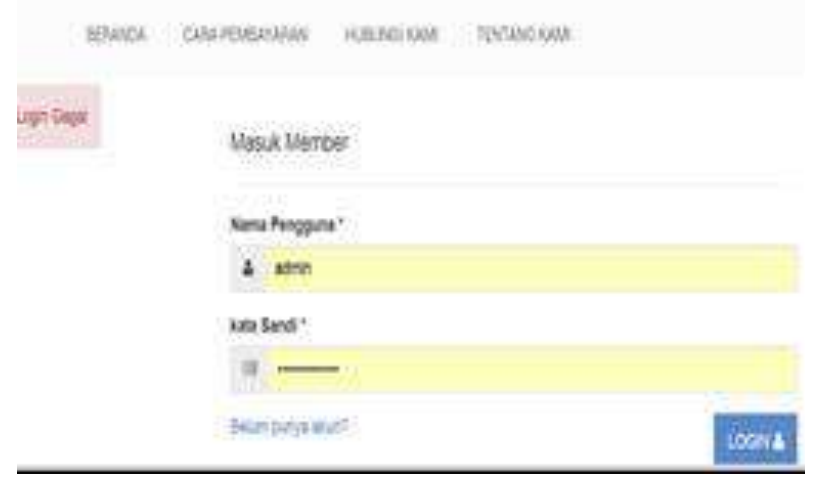

Gambar 3. Uji Halaman Login Gagal

Ketika pengguna ingin masuk ke halaman admin akan tetapi salah dalam mengisi autentikasi untuk nama pengguna dan kata sandi maka akan muncul pesan kesalahan "Login Gagal".

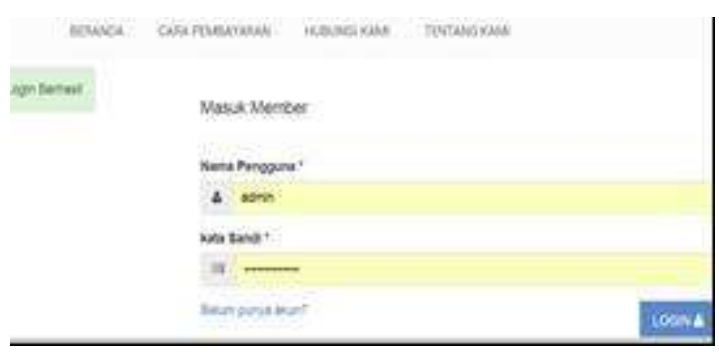

Gambar 4. Uji Halaman Login Berhasil

Kemudian halaman login diuji dengan nama pengguna dan kata sandi yang telah tersimpan pada database. Halaman login menampilkan pesan "Login Berhasil". Gambar 4. menunjukkan pesan ketika login berhasil.

\section{b. Halaman Master Data}

Pengujian dilakukan juga pada halaman master data dengan menambahkan satu jenis barang dengan detail data tertentu. Data barang meliputi foto barang, nama barang, kategori, harga, harga diskon, keterangan dan stok. Jika barang yang dimasukkan berhasil direkam oleh basis data maka sistem akan menampilkan pesan "Tambah Barang Sukses". Gambar 5. berikut merupakan hasil dari penambahan barang :

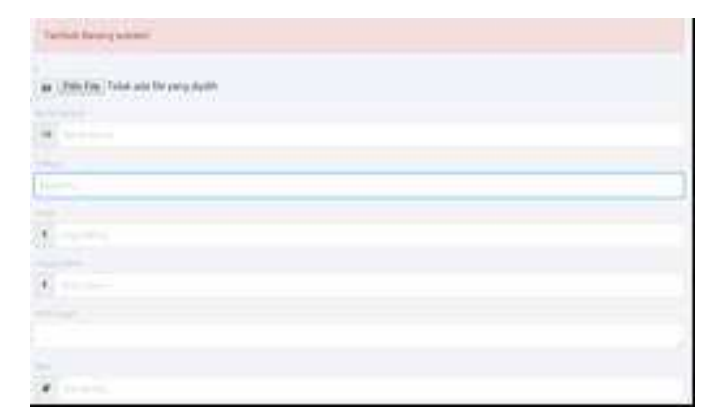

Gambar 5. Uji Halaman Tambah Barang

\section{c. Halaman Keranjang Belanja}

Pengujian terhadap halaman Keranjang Belanja, dimana member membeli barang dan sistem akan merekam sesuai dengan barang yang dipilih, harga untuk tiap satuannya dan jumlah total barang yang dibeli. Gambar 6. memperlihatkan penambahan item ke keranjang belanja.

Gambar 7. memperlihatkan pengujian terhadap perubahan data keranjang belanja. Penambahan item barang dan jumlah barang yang akan dipesan dirubah. Proses perubahan data dilakukan pada masin-masing item barang dengan menekan tombol rubah berwarna kuning yang terdapat pada setiap item barang yang masuk kedalam keranjang belanja. Berikut adalah tampilan dari kedua proses yang telah diuji. 


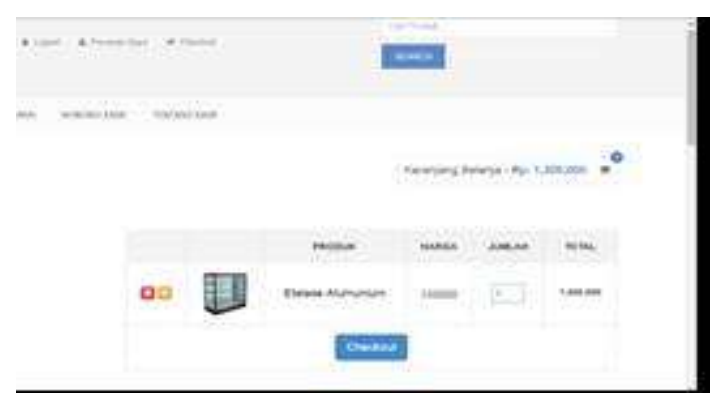

Gambar 6. Uji Halaman Keranjang Belanja

Chayadi/ Aplikasi Pemasaran Etalase Ud. Kedung Aluminium Berbasis Web/JT,Vol 9 No.1, Maret 2017, pp 41 - 48

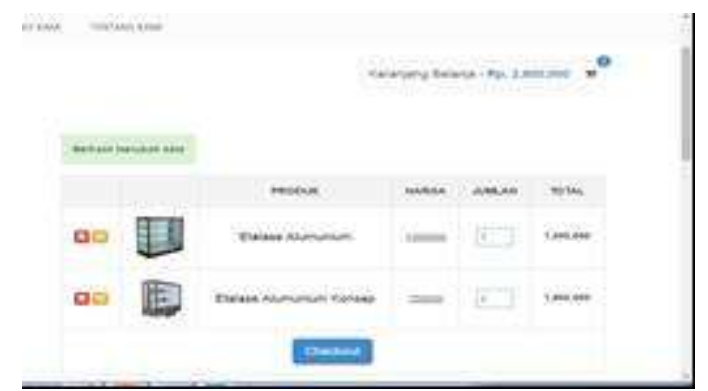

Gambar 7. Uji Perubahan Data Keranjang

\section{Belanja}

\section{Manual Program}

Manual program menjelaskan tentang tata cara penggunaan program pada Tugas Akhir ini. Pengunjung yang akan berbelanja harus mempunyai akun sebagai member. Setelah pengunjung mempunyai akun, sistem akan menyebutnya sebagai member dan harus login terlebih dahulu. Aplikasi ini menyediakan halaman khusus untuk member dan memberikan informasi tentang daftar belanja dan beberapa informasi lain terkait dengan belanja member. Langkah-langkah

pengoprasian aplikasi ini penulis bagi step by step sebagai berikut :

\section{Halaman Awal}

Halaman awal merupakan tampilan ketika pengunjung pertama kali mengakses website toko online ini. Pada halaman awal, pengunjung disuguhkan beberapa produk diantaranya terdapat beberapa kategori yaitu produk terbaru, terlaris, baru dilihat dan produk secara umum. Gambar 8. berikut merupakan tampilan halaman awal.

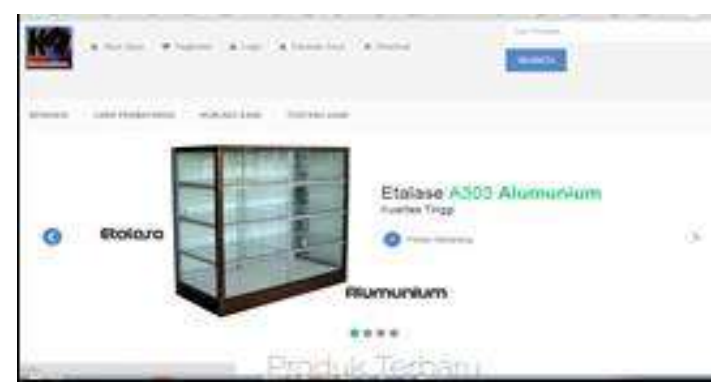

Gambar 8. Tampilan Halaman Awal

\section{Halaman Daftar Member}

Untuk berbelanja, pengunjung harus mempunyai akun sebagai member. Syarat mendaftar sebgai member adalah harus mengisi data pribadi, data pengiriman dan data pembayaran. Gambar 9. berikut menampilkan form pendaftaran member :

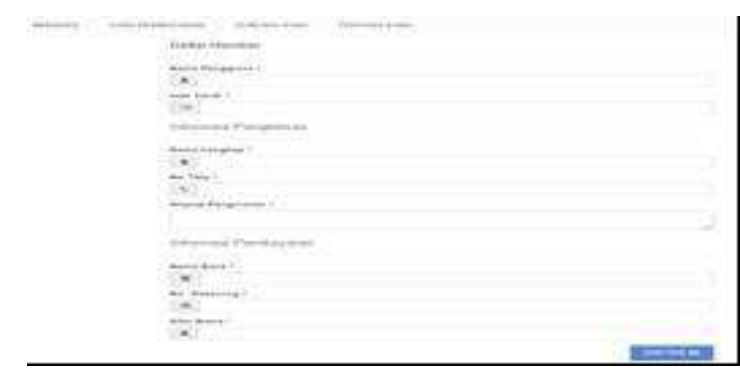

\section{Gambar 9. Tampilan Halaman Daftar Member}

Setelah mendaftar menjadi member, pengunjung dapat memilih barang yang telah ditawarkan dan memasukkannya ke dalam keranjang belanja. Terdapat dua cara untuk melakukan hal itu, yang pertama adalah melihat detail barang terlebih dahulu kemudian menambahkannya ke keranjang belanja seperti pada gambar 9. berikut : 


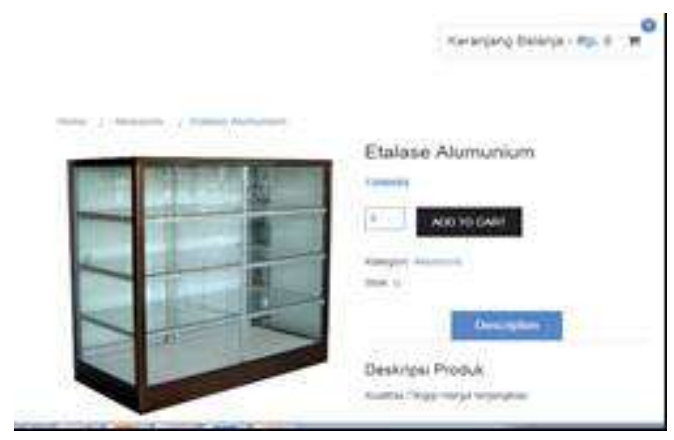

Gambar 10. Tampilan Detail Barang

Cara yang kedua adalah langsung menambahkan kedalam keranjang belanja dengan memilih tombol add to cartpada halaman awal. Setelah member menambahkan barang kedalam keranjang belanja, member dapat memasukkan ke dalam pesanan dengan cara menekan tombol checkoutpada menu bagian atas atau pada halaman keranjang belanja. Gambar 11. menunjukkan daftar keranjang belanja yang telah dipilih member dan gambar 12. menunjukkan halaman checkout

Chayadi/ Aplikasi Pemasaran Etalase Ud. Kedung Aluminium Berbasis Web/JT,Vol 9 No.1, Maret 2017, pp 41 - 48

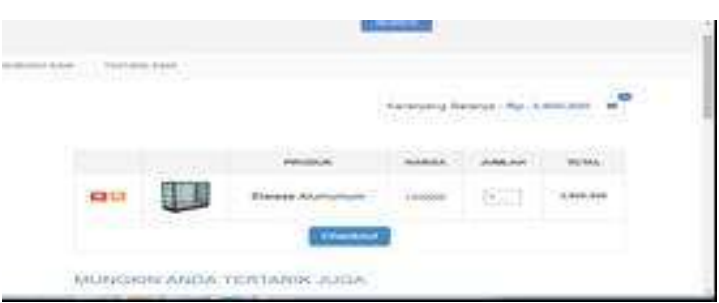

Gambar 11. Daftar Keranjang Belanja

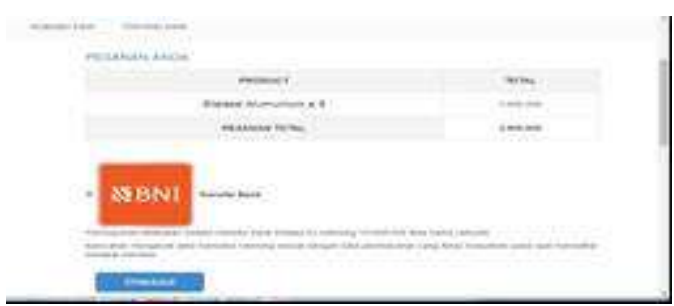

Gambar 12. Halaman checkout

Setelah melakukan checkout pada halaman yang ditunjukkan pada gambar 12. member dapat melihat daftar pesanan yang harus dibayar pada halaman member. Gambar 13. berikut menunjukkan daftar barang yang telah dipesan dengan status pending :

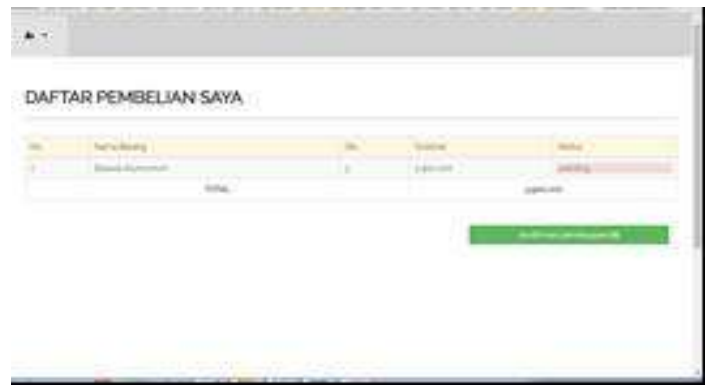

Gambar 13. Daftar Barang Yang Telah Dipesan
Ada tiga status barang pesanan pada sistem ini yaitu pending, bayar dan kirim. Yang dimaksud dengan status pending adalah sistem menunggu konfirmasi pembayaran dari member yang telah memesan barang. jika barang yang telah dipesan sudah dibayar melalui intruksi pada saat checkout, member diharuskan mengkonfirmasi pembayaran dengan cara menekan tombol konfirmasi pembayaran.

Pembayaran yang sudah dikonfirmasi akan merubah status pesanan menjadi bayar. Status bayar berarti member telah melakukan pembayaran pada tagihan pesanan dan akan tampil pada halaman admin. Gambar 13. menunjukkan pesanan member yang telah mengkonfirmasi pembayaran :

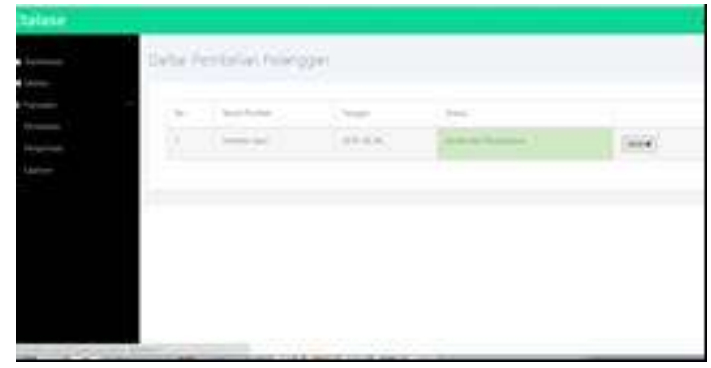

Gambar 14. Daftar Pesanan Member pada Halaman Admin

Selanjutnya, admin akan mencocokkan data pembayaran berupa nomor rekening dan nama pemilik nomor tersebut pada riwayat transaksi bank. Jika terdapat riwayat tersebut maka admin harus merubah status pesanan menjadi kirim. Gambar 15. menunjukkan detail pesanan member : 


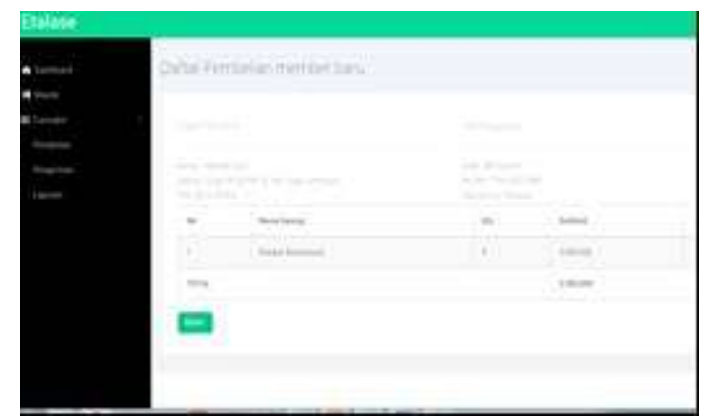

Gambar 15. Detail Pesanan Member

\section{Kesimpulan}

Dalam penulisan Laporan ini telah diuraikan bagaimana perancangan yang dapat diambil setelah beberapa tahapan dalam aplikasi Pemesanan Etalase berbasis web pada toko Etalase:
1. Aplikasi web yang dibuat menggunakan bahasa pemrograman PHP dan program dreamweaver untuk mengolah script dan dengan menggunakan program MySQL sebagai database dari data-data barang yang nantinya dapat terkoneksi dengan cepat dan mudah.

2. Website merupakan salah satu sarana yang tepat sebagai media penyampaian informasi dan promosi produk untuk memperluas skala pemasaran produk/Etalase Kedung Aluminium karena sistem tersebut menerapkan teknologi internet yang bisa diakses konsumen dimanapun dan kapanpun selama terhubung dengan jaringan internet.

3. Dengan adanya aplikasi Pemasaran Etalase, akan mempermudah bagi pembeli yang membutuhkan model etalase yang dingikan sesuai dengan usahan dan kebutuhan secara cepat dan efisien

4. Melakukan eksport data secara rutin karena dalam program ini belum ada sistem backup guna menjaga data-data tersebut tidak hilang jika terjadi kerusakan pada komputer yang di instal.

5. Melakukan perawatan komputer guna tidak sampai terkena virus yang nantinya di khawatirkan akan mengancam dari pada Aplikasi klasifikasi tersebut.

\section{PUSTAKA}

Hedisaswara. 2014. Pengertian sistem menurut para ahli. http://hedisasrawan. blogspot.co.id/2014/01/25-pengertiansistem-menurut-para-ahli.html, diakses tanggal : 21 April 2016

Ladjamudin. 2012. Sistem Informasi, http://www.noficahyono.com/2015/07/per ancangan-sistem-informasi_13.html, diakses tanggal : 25 Mei 2016

Rifka .2010. Definisi-E-Commerce http://www.binushacker.net/definisiecommerce-e-commerce-www kota dingin-cc-cc.html, Tanggal akses : 5 Mei 2016

Zaenal, Rozi a. 2015 Bootstrap Design Framework Jakarta : PT. Elex Media Komputindo. 